\title{
Makna menjadi keluarga 'teroris' bagi keluarga tersangka terorisme Amrozi dan Ali Ghufron di Desa Tenggulun, Kecamatan Solokuro, Kabupaten Lamongan
}

\author{
Scrutinizing the value of being a terorist's family for terorism suspects, \\ Amrozi and Ali Ghufron, in Tenggulun, Lamongan.
}

\author{
Anis Ulfiyatin \\ Program Magister Sosiologi \\ Fakultas Ilmu Sosial Ilmu Politik, Universitas Airlangga, Jalan Airlangga 4-6 Surabaya, \\ Indonesia \\ E-mail: anisulfiyatin@gmail.com
}

\begin{abstract}
In understanding terrorism, comprehensive perspective is strongly needed in order to explain terrorism activity in a boarder structure. The main purpose of this article is to understand the circumstances that were redefined by terrorism suspect's family about their existence in the society. Another objective of this research was also to prove the presumption of being a terrorist's family and their response of massive terrorism related reportage from media. This research uses qualitative method to comprehend value and socio-cultural context in many terrorism cases, considering terrorits's family position and situation after the bombing. Primary data were collected by in-depth interview with Amrozy and Ali Ghufron's family. The research shows that terrorist's family has redefined their identity as terrorist's family by saying "us" are different with common family around them. The difference meant in this context was about life principal that was based on Islamic value and behaviour which had to be preserved by the terrorist's family.
\end{abstract}

Keywords: terrorism, terrorist's family, identity, Islamic value

\begin{abstract}
Abstrak
Memahami terorisme tentu membutuhkan pengamatan yang menyeluruh guna dapat menjelaskan aktivitas teror itu sendiri dalam struktur makna yang lebih luas, serta memaparkan satu sudut pandang dalam melihat terorisme. Hal ini ditujukan untuk mengetahui bagaimana keluarga terdakwa terorisme meredefinisi situasi mereka sebagai keluarga teroris di tengah-tengah lingkungan masyarakat setelah adanya kasus terorisme yang dikutuk oleh sebagian besar masyarakat di Indonesia. Penelitian ini bertujuan untuk membuktikan dugaan apakah menjadi keluarga teroris itu menjadi satu kebanggan sebagai bagian dari respon terhadap pemberitaan media yang gencar dilakukan tentang anggota keluarga yang terlibat aksis teror. Penelitian ini menggunakan penelitian kualitatif untuk menggali makna dan konteks sosio-kultural dalam peristiwa terorisme terkait dengan posisi dan situasi keluarga terdakwa terorisme, kemudian menggali data primer dengan melakukan mendalam kepada para informan yang tidak lain adalah anggota keluarga dari Amrozi dan Ali Ghufron. Hasil penelitian menunjukkan bahwa keluarga teroris dari awal sudah menunjukkan proses redefinisi atas identitasnya sebagai keluarga teroris dengan mengatakan bahwa "kami" memang "berbeda" dengan keluarga lain yang ada di masyarakat pada umumnya. Perbedaan yang dimaksud terkait dengan adanya beberapa hal yang dijadikan sebagai "prinsip" hidup dan berlandaskan pada aqidah Islam yang diyakini dan harus tetap dipegang keluarga teroris.
\end{abstract}

Kata kunci: terorisme, keluarga teroris, identitas, nilai keislaman

\section{Pendahuluan}

Tulisan ini membahas tentang terorisme di Indonesia dilihat dari sudut pandang keluarga pelaku teror di Indonesia. Langsung maupun tidak, keluarga pelaku teror pasti turut menjadi sorotan khalayak ketika satu peristiwa teror terungkap. Studi ini menjadi penting karena akibat dari semua pemberitaan media dan wacana yang berkembang di masyarakat tentang satu peristiwa teror yang terungkap akan 
berdampak pada bagaimana kehidupan sosial ekonomi keluarga mereka serta bagaimana pihak keluarga teroris dalam menjalankan peranan mereka sebagai bagian dari komunitas masyarakat di lingkungan sosial sehari-hari.

Tindakan terorisme dalam kurun waktu sepuluh tahun terakhir ini menjadi salah satu ancaman bagi masyarakat dunia. Banyak peristiwa tercatat dan terekam dalam ingatan warga dunia tentang berbagai tindakan terorisme ini. Tindakan terorisme sendiri sering dialamatkan kepada mereka, sekelompok warga negara yang pada umumnya secara ekonomi, politik, sosial, budaya, dan hukum, berada dalam posisi minoritas dan tidak mendapatkan keadilan dari negaranya, sehingga mencoba melakukan suatu perlawanan dengan jalan kekerasan yang mereka pilih dengan tujuan segera direspon dan didengar oleh subyek yang menjadi sasaran utama mereka.

Beberapa kelompok telah merumuskan deskripsi tentang terorisme. Seorang tokoh Islam bernama Ayatullah Sheikh Muhammad Al Taskhiri mendefiniskan terorisme sebagai:

Ilmuwan mendefinisikan tindakan terorisme sebagai:

".... an act carried out to achieve on in human and corrupt objective and involving threat to security of mankind and violation of rights acknowledged by religion and mankind" (Salam 2005:3).

Sementara itu lembaga investigasi Amerika Serikat, Federal Bureau Investigation (FBI) secara formal mendefiniskan terorisme sebagai:

"... Terorism is the unlawful use of force or violence against persons or property to intimidate or coerce a government, civilian populations, or any segment theart, in furtherance of political or sosial objective" (Salam 2005:3).

Jika dilihat dari definisi di atas maka terorisme memiliki landasan dan sekaligus tujuan objektif yang kerap kali dialamatkan pada kelompok-kelompok dengan tujuan sosial politik tertentu. Dewasa ini terorisme diidentikkan dengan latar belakang agama, khususnya Islam. Hal ini semakin dikuatkan dengan adanya kasus terorisme yang berhasil mengguncang Negara Amerika, yaitu dengan peristiwa hancurnya gedung WTC di Amerika pada 11 September 2001, yang kemudian diidentifikasi sebagai tindakan yang dilakukan oleh umat Islam, khususnya penganut jaringan Islam Alqaeda. Tidak heran jika setelah peristiwa tersebut, Islam kemudian selalu dihubung-hubungkan dan distigmatisasi sebagai agama yang mendukung tindakan kekerasan dan terorisme ini, stigma ini semakin dikuatkan dengan maraknya gerakan-gerakan politik Islam yang bermunculan dan tersebar luas di seluruh dunia dalam sepuluh tahun terakhir ini (Akaha AZ 2002:51-72).

Indonesia sebagai salah satu negara yang dihuni oleh penduduk dengan mayoritas beragama Islam, menjadi sasaran sempurna dalam diskursus tindakan terorisme ini. Wacana tentang banyaknya jaringan dan gerakan Islam fundamental yang tumbuh dan berkembang di Indonesia menjadi salah satu indikator tersendiri dari tuduhan-tuduhan tersebut. Sikap dan tuduhan yang ditujukan kepada para penganut agama Islam ini sendiri bukan tanpa preseden. Jika dilihat dari sudut pandang sosiologi politik, mengerasnya sikap Islam Politik juga seiring dengan kebijakan politik luar negeri Amerika Serikat yang semakin keras, terutama menyangkut konflik Israel-Palestina dan rencana serangan ke Irak, justru memberikan amunisi bagi reaksi yang semakin kencang dari kalangan Islam Politik ini sendiri.

Aksi terorisme berdalih agama adalah yang paling banyak terjadi di Indonesia dalam kurun satu setengah dekade terakhir. Tercatat kejadian mulai dari pengeboman yang terjadi di kedutaan besar Filipina di Jakarta pada 1 Agustus tahun 2000, Bom Bali I yang meledak di Paddy's club pada 12 Oktober 2002 yang menyebabkan 202 jiwa melayang yang mayoritas berkewarganegaraan Australia. Aksi teror ini juga diikuti dengan teror-teror lainnya di tahun-tahun berikutnya, baik di Ibukota Jakarta seperti di Kedutaan besar Australia pada 9 September 2004, Hotel JW Marriot dan Ritz Charlton 17 Juli 2009, ataupun di daerah lainnya seperti Gereja Immanuel di Palu, Sulawesi Tengah pada 12 Desember 2004 dan Nyoman Kafe di Jimbaran Bali pada 1 Oktober 2005. Semua jejak rekam kasus pengeboman yang pernah terjadi di Indonesia tersebut menjadikan terorisme ini menjadi satu diskursus yang hangat di Indonesia, sekaligus menjadi stereotype bahwa Indonesia sebagai salah satu 
negara yang menjadi sarang perkembangan dan aksi terorisme (Akaha AZ 2002:43-49).

Studi tentang terorisme di Indonesia telah banyak dilakukan oleh para ilmuwan. Studi-studi tersebut kebanyakan mengkaji tentang dimensi sosio-kultural dan hubungannya dengan agensi individu pelaku teror di Indonesia. International Crisis Group (ICG) dalam studinya mengkategorikan bentuk gerakan Islam yang mengusung konsep jihad dengan berlatar pada klaim kondisi umat Islam yang tertekan dan berada pada pusaran gerakan Zionis Yahudi global (Hilmy 2009: 23-31). Rosyadi (2004), dalam kaitannya dengan merebaknya wacana jihad dan terorisme, mengamati proses redefinisi jihad yang dilakukan organisasi masyarakat (ormas) berbasis agama Islam dalam melakukan konter wacana terhadap penggunaan kekerasan berdalih agama. Studi-studi yang telah ada sebelumnya cukup komprehensif, namun melupakan arena lain tempat insternalisasi sekaligus eksternalisasi nilai dan wacana itu dilakukan, yakni keluarga. Melalui studi ini penulis ingin melihat bagaimana kedudukan keluarga pelaku teror dalam rekonstruksi nilai dan keaktoran teror di Indonesia. Studi yang telah dilakukan menempatkan subyek penelitiannya pada para santri, sedangkan pada penelitian ini memfokuskan secara langsung kepada para anggota keluarga teroris.

Dalam memahami terorisme tentu membutuhkan pengamatan yang menyeluruh guna dapat menjelaskan aktivitas teror itu sendiri dalam struktur makna yang lebih luas, serta memaparkan satu sudut pandang dalam melihat terorisme dengan tujuan untuk mengetahui bagaimana keluarga terdakwa terorisme meredefinisi situasi mereka sebagai keluarga teroris di tengah-tengah lingkungan masyarakat setelah adanya kasus terorisme yang dikutuk oleh sebagian besar masyarakat di Indonesia, selain itu juga ingin membuktikan dugaan apakah menjadi keluarga teroris itu menjadi satu kebanggan sebagai bagian dari respon terhadap pemberitaan media yang gencar dilakukan tentang anggota keluarga yang terlibat aksis teror.

\section{Metode Penelitian}

Untuk menggali makna dan konteks sosio-kultural dalam peristiwa terorisme terkait dengan posisi dan situasi keluarga terdakwa terorisme, maka dalam penelitian ini menggunakan penelitian kualitatif. Penelitian kualitatif adalah suatu metode penelitian yang ditujukan untuk mencari makna serta menganggap bahwa realitas sosial selalu bersifat ganda (Suyanto dan Sutinah 2005:166-168). Realitas sosial merupakan hasil konstruksi pemikiran dan bersifat holistik, serta suatu pendekatan yang bertujuan untuk memahami perilaku manusia dari sudut pandang mereka sendiri/sudut pandang obyek yang diteliti (Ritzer 2004:317-319).

Dalam menggali makna yang ada pada satu realitas, maka pendekatan yang digunakan dalam penelitian ini adalah pendekatan interpretatif. Pentingnya menggunakan pendekatan interpretative ini adalah sebagaimana dijelaskan oleh Ritzer (2004) bahwa dalam berperilaku seorang individu selalu mempertimbangkan proses pemaknaan dan interpretasi atas segala realitas yang dihadapinya sebelum akhirnya memutuskan memberikan respon atas stimulus yang didapatkannya dalam proses interaksi sosial tersebut. Proses pemaknaan dan interpretasi oleh aktor inilah yang perlu dilihat lebih dalam. Hal ini untuk menghindari bias makna yang terjadi ketika melihat fenomena tindakan teror. Pendektan interpretif inilah yang digunakan peneliti dalam memahami bagaimana keluarga terdakwa terorisme menginterpretasikan dirinya dan keluarganya ditengah arus wacana publik yang hanya melihat mereka sebagai keluarga para 'devian'.

Sementara itu dalam penelitian ini, peneliti membatasi konteks satu peristiwa sebagai menggunakan kasus Bom Bali I dengan terdakwa Amrozi dan Ali Gufron yang terjadi pada tahun 2002 sebagai setting penelitian. Setting ini melihat peristiwa Bom Bali I sebagai satu rangkaian panjang yang salah dua dari aktor-aktor yang terlibat dapat diamankan oleh pihak keamanan dalam keadaan hidup dan membeberkan panjang lebar latar belakang di balik pengeboman saat menjalani pemeriksaan oleh penyidik. Melalui proses panjang kedua terdakwa ini kemudian menjadi sorotan internasional menjelang eksekusi hukuman mati yang diberikan oleh kejaksaan. Media nasional dan internasional 
pun turut menyoroti peristiwa panjang ini, termasuk menyoroti keberadaan keluarga mereka. Penentuan setting penelitian ini penting karena tidak hanya memberikan batasan-batasan penelitian isu pokok penelitian tetapi juga menentukan subyek penelitian (Suyanto 2005).

Selanjutnya dalam penelitian ini peneliti membagi subyek penelitian sesuai dengan peran dan kategori informasi data yang disampaikan. Pertama adalah informan kunci yang diasumsikan mengetahui dan membantu memberikan semua informasi yang dibutuhkan. Dalam hal ini AB adalah informan kunci yang sehari-hari adalah seorang salah satu keluarga dan tenaga pengajar dan sekaligus anggota dewan pendiri dari yayasan Pondok Pesantren Al-Islam yang dimiliki keluarga besar tersangka terorisme ini sendiri. Kedua adalah informan utama. Informan utama ini adalah mereka anggota keluarga terdakwa teror Bom Bali I. Pada akhirnya yang berkenan untuk dijadikan informan adalah AT yang merupakan kakak kandung Amrozi dan Ali Gufron; istri kedua Amrozi berinisial AS; dan F yang merupakan anak kandung Amrozi. Untuk mendapatkan data, maka informan menerapkan teknik wawancara mendalam (indepth interview). Tehnik ini dilakukan dengan cara melakukan wawancara dan diskusi yang intensif dengan subyek hal yang dianggap penting untuk keperluan pelaporan dan penyimpulan hasil penelitian sendiri (Suyanto dan Sutinah 2005).

\section{Hasil Penelitian dan Pembahasan}

\section{Konstruksi identitas: menjadi anggota keluarga}

Keluarga dari tersangka kasus terorisme bom Bali (Amrozi dan Ali Ghufron) ini adalah sebuah keluarga yang terpandang dalam masyarakat, selain karena berdasarkan silsilah kedua orang tua almarhum adalah masih memiliki keturunan seorang kyai atau ulama sekaligus menjadi tokoh masyarakat yang cukup terpandang, keluarga teroris ini juga merupakan penduduk Desa Tenggulun yang bisa dikatakan memiliki status sosial yang tinggi dari segi ekonomi. Sebagaimana masyarakat yang tinggal di daerah pedesaan pada umumnya, tolak ukur yang dipakai untuk menyatakan seseorang terpandang dan atau mampu secara ekonomi, akan selalu didasarkan pada jumlah kepemilikan sawah pertanian, ladang, perkebunan, atau bahkan dari jumlah kepemilikan ternak yang dimiliki masyarakat tersebut, begitu juga dengan apa yang dialami oleh keluarga teroris ini, dimana status sosial ekonominya cukup terpandang ditengah-tengah penduduk Desa lainnya.

Hal lain yang menjadi perhatian penduduk Desa atas keberadaan keluarga teroris ini adalah karena pengetahuan agama yang dimiliki oleh keluarga teroris sendiri, bahkan ayah dari Amrozi ini juga merupakan salah satu sesepuh Desa yang sangat disegani oleh semua penduduknya. Keluarga teroris ini juga memiliki sebuah bangunan Masjid pribadi yang kemudian dihibahkan untuk kalangan masyarakat umum dan terletak tidak jauh dari rumah. Pertimbangan lain adalah karena dalam mayoritas penduduk kampung, ada semacam perasaan segan dan bahkan takut dengan keluarga teroris ini karena sikap tegas dan kerasnya pemikiran serta prinsip hidup yang mereka pegang terutama dalam hal penegakan syariat agama.

Perlu diketahui bahwa penduduk Desa Tenggulun adalah masyarakat yang secara keseluruhan memeluk agama Islam, dan dari seluruh penduduk tersebut, mayoritas menjadi pengikut dari organisasi kemasyarakatan NU (Nahdlotul Ulama). Dimana dalam seluruh ajaran dan prinsip yang diyakini oleh para penganut NU adalah serangkaian upaya pelestarian tradisi kejawen dalam Islam seperti dengan adanya berbagai tradisi keagamaan dan ritual-ritual yang menyangkut proses kehidupan selama individu hidup sampai mati seperti berbagai ritual upacara kejawen untuk memperingati kelahiran, perkawinan, dan juga pada peristiwa kematian. Semua ritual keagamaan inilah yang juga belum bisa ditinggalkan oleh penduduk Desa Tenggulun, sehingga tidak mengherankan jika kemudian ada cerita tentang tindakan kekerasan dan anarkisme yang dilakukan oleh salah satu anggota keluarga teroris dalam upayanya memberantas berbagai kemusyrikan dan perilaku-perilaku bid'ah yang dilakukan oleh sebagian besar penduduk Desa Tenggulun. 
Sebuah "kewajaran" bagi keluarga teroris sendiri untuk terus berupaya memberantas dan memerangi berbagai tindakan syirik yang ada dalam lingkungan Desa Tenggulun ini. Karena sebagaimana dijelaskan sebelumnya anggota keluarga teroris ini adalah anggota penganut organisasi Muhammadiyah yang secara prinsip dan ritual keagamaan, sangat bertolak belakang dengan apa yang diyakini penduduk Desa Tenggulun yang lain. Hebatnya meskipun secara jumlah anggota keluarga teroris ini tentu saja jauh lebih sedikit jika dibandingkan dengan jumlah penganut NU secara keseluruhan, tetapi kualitas dan totalitas perjuangan yang dilakukan oleh keluarga teroris juga kekonsistensian tindakan mereka ini cukup tinggi. Sebagaimana usaha keluarga teroris dalam memerangi apa-apa yang menurut agama salah, usaha tersebut tidak hanya secara lisan dan memberikan contoh tindakan langsung, tetapi tidak jarang keluarga teroris melakukan perlawananperlawanan dengan memberikan penolakan secara langsung dan tegas dan bahkan terkesan "menghalalkan" penggunaan segala cara kekerasan untuk memerangi tindakan yang tidak benar menurut ajaran agama Islam tersebut.

Sebagaimana penuturan salah satu tersangka kasus terorisme bom Bali, Amrozi, dalam buku terakhir yang masih sempat ditulisnya, diceritakan bahwa menurutnya tidak ada yang perlu ditakuti dan tidak ada batas toleransi untuk setiap masyarakat yang secara sengaja menunjukkan kejahiliahannya dalam melakukan berbagai tindakan musyrik tersebut. Kedua orang tua Amrozi dan Ali Ghufron sendiri dan saudara-saudara yang lain, juga selalu dibiasakan untuk terus menempatkan urusan agama pada prioritas utama, baik dalam amalan harian (amaliah yaumiyah) sampai pada amalan-amalan lain yang sifatnya akan merusak dan menghancurkan Islam, maka tidak ada yang lebih baik untuk bisa dilakukan guna membela agamanya, selain dengan menggunakan cara kekerasan, jika sebelumnya teguran berupa lisan dan contoh tindakan yang benar tidak juga didengarkan atau diabaikan.

Keberadaan dan dukungan orang tua terlihat cukup mendominasi dalam alasan-alasan dan berbagai faktor yang menjadi dasar terbentuknya perilaku "keras" oleh Amrozi tersebut atas urusan agama, sebagaimana pernyataannya tentang sosok dan peran seorang Nur Hasyim, dalam buku biografinya berikut ini;

“...yang saya ketahui tentang ayah adalah bahwa beliau seorang yang taat beragama, mulai dari masalah yang kecil sampai masalah yang besar. Hal ini yang saya ketahui karena beliau sangat menekankan kepada anak-anaknya dalam masalah ibadah; seperti sholat, membaca Al-Qur'an dan shoum. Dan beliau juga menekankan kepada anak-anaknya untuk senantiasa menyambung silaturrahim kepada saudara-saudara, kaum kerabat, handai taulan dan juga kepada orang-orang sholih. Oleh karena itu beliau akan merasa sedih jika mendapati anaknya tidak berakhlaq mulia kepada orang lain."

Pernyataan diatas memperlihatkan bagaimana proses penanaman nilai-nilai agama mulai dan terus dilakukan oleh kedua orang tua kepada anak agar terus mengutamakan pengamalan berbagai ajaran dan syariat agama Islam. Informan juga sempat menceritakan bagaimana kesan lain yang diingatnya dari seorang ayah yang dibanggakannya tersebut;

“...ayah juga sering bercerita kepada saya tentang perjuangannya dalam melawan kaum penjajah kafir Belanda dalam rangka membela kemerdekaan. Lebih dari itu beliau juga mencita-citakan tegaknya syari'at Islam di Negara Republik Indonesia. Ayah saya mungkin dilahirkan ditengahtengah keluarga yang paham keagamaannya mengikuti paham Nahdlatul Ulama' (NU). Meskipun demikian, beliau sangat tegas dan tidak kompromi dengan segala bentuk syirik, sebagaimana dalam prinsip paham Muhammadiyah. Contohnya Takhayul, bid'ah dan khurofat. Ayah sangat anti dengan acara yasinan di kuburan, haul-haulan, jum'at wage-an, peringatan kematian, majelis kadiran, qunut shubuh, atau tarawih 23 rakaat. Beliau juga tidak mau menyentuh makanan yang berasal dari selamatan kematian. Bahkan beliau tidak mau bermakmum di belakang imam yang menurut beliau ahli bid'ah, kecuali sholat Jum'at..."

Selain kisah di atas, kisah lain juga dapat dilihat dari cerita AB. Selain sebagai guru dan salah satu orang yang memiliki pengaruh di Pondok Pesantren Al Islam, AB ternyata adalah sesosok orang tua yang memang juga di-tua-kan atau di "wong $n e$ " dalam keluarga besarnya, maupun juga dalam keluarga batihnya sendiri, sosok orang tua biasa yang sebagaimana umumnya juga terlihat sangat 
"hangat" dengan anak-anaknya. Namun Ia tetap mewarisi tradisi ayahnya ketika mendidik AB sedari kecil untuk selalu mengedepankan agama. Ia tetap keras bahwa tindakan mensekutukan Allah itu adalah dosa besar. Sebagaimana dalam satu wawancara, AB menjelaskan

"Sudah barang tentu. jadi.. sebagaimana yang dicontohkan ulama-ulama terdahulu.. siapa..? termasuk ulama-ulama yang diabadikan oleh Allah yang diabadikan dalam Alquran yang bernama.. Luqman. Luqman sendiri bicara kepada anaknya, Yaa bunayya laa tusyrik billah! Itu.. itu penekanannya seorang Luqman kepada anaknya biar anaknya tidak melakukan suatu tindakan yang sampai menyekutukan Allah...! Karena syirik adalah suatu tindakan yang.. yang sangat menyesatkan..! makanya saya pribadi juga kemudian sangat memperhatikan syariat itu dalam mendidik anak saya sendiri. Ya. karena seperti itu juga yang saya dapatkan dari pak'e saya waktu saya masih kecil.. apapun selalu dilihat dari segi kepentingan agama dulu. Dan saya mematuhinya juga.."

Secara keseluruhan dalam sub bab tentang proses pembentukan identitas sebagai anggota keluarga teroris ini peneliti memperlihatkan tentang bagaimana proses sosialisasi yang berjalan dalam lingkungan keluarga dari para tersangka terorisme ini. Faktor apa yang kemudian sampai menyebabkan lahir dan berkembangnya pemikiran-pemikiran dan keyakinan-keyakinan terhadap ajaran-ajaran agama yang tertanam kuat dalam diri masing-masing individu dalam keluarga, sebagaimana yang kemudian terlihat dalam perilaku dan tindakan dua anggota keluarganya yaitu pada diri Amrozi dan juga Ali Ghufron.

\section{Redefinisi identitas diri anggota keluarga pasca kasus terorisme}

Cerita tentang terjadinya peristiwa Bom Bali I yang melibatkan keluarganya merupakan satu hal yang serius bagi AT. AT sendiri kini menjadi perwakilan dari pihak keluarga yang diserahi tanggungjawab untuk memimpin yayasan pendidikan Pondok Pesantren Al-Islam miliki keluarga. Menurut pandangan AT, peristiwa Bom Bali I menjadi sebuah pelajaran yang teramat berharga dalam kisah perjalanan hidupnya. Akibat dari aksi terorisme yang dilakukan oleh saudaranya ini juga, yang pada akhirnya menjadikan dirinya dan keluarga besarnya serta yayasan pendidikan Pondok Pesantren AlIslam yang diasuhnya menjadi sebuah entitas masyarakat yang "terkerdilkan" secara hukum, ekonomi, politik, dan dunia sosialnya. Karena itu sikap yang seharusnya ditunjukkan oleh AT sendiri di mata masyarakat luas terkait dengan statusnya sebagai bagian dari keluarga teroris ini adalah harus menunjukkan dan mampu meyakinkan masyarakat luas yang ada tentang kebenaran dari apa yang telah dilakukan oleh saudara-saudaranya.

"Dalam Alquran ya ada dalilnya. Jelas.. Kalau orang Islam sudah diperangi.. ya gak masalah. Dibenarkan untuk memerangi mereka orang-orang kafir itu. Orang kafir sendiri itu kan ada dua. Jadi, satu, ada yang dinamakan kafir Dlimmi yang sikapnya tidak mengganggu umat Islam, nah kepada mereka ini, umat muslim juga wajib mempergauli mereka dengan baik didunia, istilahnya kan Lakum diinukum waliyadiin, sedangkan kafir yang satunya ya yang musuhi dan merongrong umat muslim ini! lah kalau kafir seng memerangi wong Islam, yo ra masalah mereka juga diperangi..!"

"Kalau sudah diperangi wong kafir, yo ayo diperangi! Ya tapi kalau gak ada maslaah yo.. gak boleh. nah kalau kafir yang menjatuhkan Islam kan artinya wes gak bisa lagi diapiki.. ya seperti seng nek Bali itu kan? Ya sudah tidak mungkin dimaafkan. Meskipun kan di bom seperti itu juga belum bisa dikatakan berhasil sampai sekarang. Ya.. buktinya sampai sekarang kemaksiatan yang ada disana juga masih ada kan..??"

Dengan pendapat yang diutarakan oleh AT tersebut, maka AT tidak memiliki kendala yang berarti pada dirinya secara pribadi terkait adanya anggapan masyarakat luas yang mengatakan bahwa apa yang dilakukan saudaranya tersebut sebuah tindakan yang sifatnya tercela, karena justru menurut AT semua itu adalah sebuah konsekuensi dari tindakan mulia yang berlandaskan pada aqidah yang disyari'atkan oleh agama Islam sendiri.

Senada dengan AT, AS juga melihat tindakan Amrozi yang tak lain adalah suaminya adalah sesuatu yang dibenarkan. Mengingat selama ini sebagaimana penuturan para tersangka sendiri kepada AS bahwa mereka melihat secara langsung "kebiadaban" yang dilakukan oleh pihak "kafir" dalam menghancurkan dan menyiksa saudara sesama muslim dengan tidak manusiawi seperti yang terjadi di 
Negara-negara Islam; Irak, Afganistan, Palestina, dan juga di beberapa daerah di Indonesia adalah sebuah keadaan yang memotivasi dan menuntut mereka untuk melakukan tindakan yang sama pada kaum "kafir" tersebut.

“... meskipun saya sendiri pada awalnya tidak tahu sama sekali dengan apa yang direncanakan dan lalu diperbuat oleh suami saya.. tapi jauh sebelum Abi-nya Khaulah ditangkap dan lalu diadili karena mengaku sebagai pelaku tindakan pengeboman itu. almarhum sering sekali menceritakan kepada saya.. ya.. tentang perkembangan Islam di dunia, ya.. termasuk juga cerita kesusahan saudara muslim kita yang ada di Negara-negara muslim seperti muslim di Palestina.. Afganistan.. ya.. di Ambon.. Maluku.. yang memang almarhum kan tahu langsung kejadian dan keadaan mereka itu bagaimana. jadi ya.. memang sering.. beliau itu mengutarakan kesedihan dan keprihatinannya kepada mereka-mereka itu. makanya kalau pada akhirnya dari umat muslim sendiri muncul tindakan pembalasan serupa untuk Amerika dan sekutunya la'natullah itu.. ya itu ganjaran yang setimpal buat mereka.."

Namun demikian, AS juga mengaku bahwa dalam kesehariannya di lingkungan masyarakat Tenggulun, pendapat-pendapat yang kurang menguntungkan tersebut juga ada, dan AS menganggap hal tersebut wajar saja. Adapun usaha AS dalam membawa identitasnya sebagai janda dari tersangka terorisme ini dalam masyarakat bisa dikatakan sangat "membumi", sebagaimana pernyataannya dalam wawancara berikut ini

“ saya kan juga warga Desa Tenggulun, sama dengan warga-warga yang lain.. apalagi saya ini kan pendatang disini.. jadi ya.. yang saya lakukan untuk tetap bisa berinteraksi dengan masyarakat Tenggulun sendiri.. ya.. pintar-pintar saya bagaimana membawa diri saja.. apapun yang dilakukan oleh almarhum adalah suatu yang juga saya sendiripun nggak tahu apa-apa, mbak.. saya sangat paham walaupun saya istri dari beliau, bukan berarti saya bisa tahu semua yang dilakukan oleh beliau.. jadi biarlah yang baik-baik saja yang dikenang oleh masyarakat sini.. dan mudah-mudahan amal ibadah almarhum diterima Allah subhanahu wata'ala. Saya sendiri.. ya.. saya bagaimana bisa tetap meneruskan amal kebaikan beliau kepada anak-anak saya.. mendidik anak-anak saya.. dan saya harus tetap kuat dengan semua cemoohan yang datang. jadi ya.. saya mencoba menunjukkan kepada tetangga-tetangga saya. khususnya..bahwa saya adalah sebagaimana warga Tenggulun yang lain. Ya hidup rukun dengan mereka semua.. ya Alhamdulillah sejauh ini.. mereka bisa memperlakukan saya dengan baik dan justru sangat menghormati kami.. karena kami juga selalu berusaha menjaga hubungan baik tersebut.."

Ada kata-kata bijak yang menyatakan bahwa kedewasaan seseorang tidak selalu ditentukan oleh umur yang telah dicapai seseorang, tetapi lebih ditentukan pada seberapa banyak pengalaman hidup yang pernah dialami dan menimpa individu tersebut. Kiranya kalimat ini cukup mewakili apa yang juga dialami oleh F dalam perjalanan hidupnya sampai sekarang. Sebuah status sosial yang sifatnya taken for granted harus disandangnya, menjadi anak dari seorang Amrozi yang kemudian lebih dikenal dengan seorang teroris, juga dihadapkannya $\mathrm{F}$ pada kenyataan bahwa dalam usianya yang masih sangat belia, $\mathrm{F}$ harus menjadi seorang yatim dan dipaksa menerima sebuah kenyataan pahit bahwa sesosok abi yang begitu dicintainya harus ditembak mati atas nama "keadilan" dan kepatuhan kepada "hukum" formal yang berlaku di Indonesia.

"meskipun F tidak ditakdirkan oleh Allah bisa menikmati waktu yang cukup lama untuk bisa bersama abi, tapi InsyaAllah yang baik-baik yang tetap $F$ ingat dari sosok beliau.. F juga bangga dengan apa yang sudah dilakukan oleh abi karena $F$ tahu abi InsyaAlah melakukan tindakan yang benar di mata Allah SWT..”

Karena sejauh ini setelah wafatnya sang abi, F belum pernah berinteraksi secara intens dengan masyarakat umum dan hidup bersama-sama setiap hari dengan keluarga besarnya di Tenggulun, maka tidak banyak kesan yang dimilikinya terkait persepsi yang diutarakan masyarakat luas atas abi-nya tersebut. Kesan yang selama ini didapatkannya dari teman-teman dalam lingkungan Pondoknya terhadap sang abi adalah sebuah kesan yang "baik" dan bahkan secara tidak langsung menjadikan dirinya sebagai seorang santriwati yang disegani oleh banyak pihak yang ada disekelilingnya. 


\section{Makna menjadi keluarga teroris}

Terkait adanya anggapan yang mengarah pada adanya semacam labeling yang diarahkan kepada saudara-saudaranya sebagai seorang teroris, maka AB memiliki jawabannya sendiri. Diakuinya pengertian dari terorisme sendiri menurut $\mathrm{AB}$ adalah sebuah tindakan yang sifatnya mengandung unsur menakut-nakuti baik dengan menggunakan lisan atau ancaman saja atau juga dengan cara menggunakan kekerasan, dan apa yang dilakukan oleh saudara-saudaranya dengan melakukan aksi pengeboman di tempat umum, yaitu dilakukan di sebuah tempat hiburan malam yang terletak di daerah Kuta-Bali, adalah suatu tindakan yang sifatnya juga membuat panik dan menakut-nakuti warga, karena kebetulan bom yang menjadi sarana aksi jihad tersebut adalah sesuatu yang berbahaya, maka tentu saja kemudian apa yang dilakukan oleh Amrozi dkk. digolongkan juga sebagai sebentuk aksi terorisme.

Menurut $\mathrm{AB}$ jika kita mencoba mengartikan tindakan terorisme dengan pengertian demikian, maka bukan saja Amrozi, Ali Ghufron, dan kawan-kawannya yang lain yang kemudian bisa disebut sebagai seorang teroris, tetapi juga bisa dipakai untuk menunjuk siapa saja yang melakukan unsur-unsur tindakan yang sama, yaitu dalam prosesnya menakut-nakuti dan meresahkan masyarakat.

“... Dan.. apa ya..? kalau tidak ada tindakan yang.. yang menakut-nakuti.. dan tindakan atau ketika menakut-nakuti itu kan tidak.. tidak.. secara tiba-tiba atau barang baru toh? Rasulullah dan para sahabatnya itu kan juga menakut-nakuti orang kafir toh? Lah kalau hanya karena menakut-nakuti kemudian diistilahkan teroris, teroris adalah perbuatan tercela. Ya berarti rasulullah juga masuk sebagai teroris! dan misalnya sampeyan punya harta, dan sampeyan mempertahankan harta sampeyan dengan menggunakan senjata untuk menakut-nakuti, apakah itu juga teroris? Atau sampai kepada, naudzubillah, suami atau istri direbut, apa juga dianggap teroris? Ya gak juga toh..?”

Terkait banyaknya kasus terorisme yang dilakukan dengan menggunakan cara yang sama sebagaimana yang dilakukan Amrozi dan Ali Ghufron ini, AB menganggap apa yang dilakukan oleh banyak tersangka terorisme saat ini sudah banyak yang salah sasaran dan tidak bisa dibenarkan, sehingga menurut $A B$ apa yang dilakukan oleh saudaranya - Amrozi dan Ali Ghufron - dengan apa yang dilakukan oleh beberapa orang yang juga mengaku melakukan bom syahid, maka hal itu dikatakan oleh $\mathrm{AB}$ sebagai sesuatu yang berbeda.

\footnotetext{
“ Tapi yang sekarang banyak terjadi tindakan yang samajuga..kan mengekor gitu. Ya itu kan.. apa.. kurang bijak menurut saya. Jadi sudah tidak murni lagi, tidak benar sasarannya, kurang pas begitu. Jadi yang sekarang terjadi sudah kurang pas.. kurang tepat lagi. Itupun.. tidak semuanya begitu.. jadi melihat.. e.. background masing-masing atau kelompok. Tentang memberikan pengertian Islam sendiri. Islam itu kan Rohmatan lil'alamin, ya.. Islam itu harus damai.. itu kan yang diharapkan atau yang di.. ya yang diharapkan bahwa Islam itu jangan samapai punya musuh. Itu dari mana kamusnya? Bahkan dimasa para nabi para sahabat itu juga banyak musuhnya!"
}

Poin paling penting dalam pernyataan $\mathrm{AB}$ ini adalah pada pendapatnya tentang apa yang selama ini memang dirasakan dan dipahaminya sebagai sebuah refleksi pembentukan makna atas dirinya dan keluarga yang telah di label sebagai bagian dari keluarga teroris, sebagaimana secara ringkas dinyatakannya berikut ini:

“Terkait dengan keadaan, kami tidak mereka ada perasaan..perasaan.. terisolir dari perilaku masyarakat, karena kepergian atau peristiwa yang menimpa keluarga. Bahkan, bahkan ada perasaan bangga! Dan itu terbukti karena.. itu hal yang memang, menurut saya itu rohmat Allah. Secara.. secara tiba-tiba, harkat dan martabat yang diberikan kepada keluarga.. betul-betul kami rasakan. Sampai.. mudah-mudahan itu menjadi sebuah.. buah dari pada perilaku-perilaku yang menurut Allah itu dinilai benar! sehingga imbasnya itu kepada keluarga. Untuk tidak malah.. apa ya..? tidak didudukkan dalam status yang rendah malah terangkat. Bahkan kalau saya ketika kumpul-kumpul di komunitas. ya.. teman-teman organisasi sosial keagamaan maupun ditingkat birokrasi, itu.. malah.. apa ya..? e.. ya malah di.. "uwongke”. di "wongno” begitu. " 
Jadi makna yang kemudian muncul dan dimiliki oleh $\mathrm{AB}$ sebagai salah satu bagian dari keluarga teroris ini, justru sebuah rasa "kebanggaan" tersendiri yang dimilikinya dan juga keluarganya. Sebagaimana dijelaskan juga oleh $\mathrm{AB}$, setelah adanya kasus yang menimpa keluarganya tersebut, $\mathrm{AB}$ merasa bahwa kedudukan yang dimilikinya dalam status sosialnya di masyarakat justru lebih terhormat dari pada sebelumnya, dan oleh masyarakat dan lingkungannya AB justru dianggap sebagai seseorang yang "di-wong-no", seseorang yang cukup berpengaruh dan diperhatikan dalam setiap pergaulannya dalam dunia sosialnya di masyarakat. "Kebanggaan" ini juga terlihat selama proses wawancara ini berlangsung, dimana $\mathrm{AB}$ tidak pernah lupa menyebut kedua adiknya yang menjadi tersangka teroris ini dengan sebutan seorang "syuhada". Karena memang di mata AB tindakan yang dilakukan oleh saudaranya tersebut adalah sebuah kebenaran, sehingga gelar yang patut disandangkan untuk mereka adalah sebagai seorang "syuhada" dan bukan sebagai seorang teroris.

Di sisi lain, AS juga merasakan hal senada. AS sadar benar ketika memutuskan untuk menikah dengan Amrozi, menjadi istri dan sekaligus pendamping hidup dari seorang mujahid memang akan sangat berbeda dengan peran istri pada umumnya. Dimana dalam prinsip kehidupan mereka, istri tidak hanya sebagai partner dalam mengurus dan membina rumah tangganya saja, lebih dari itu seorang istri mujahid harus mampu menjadi "penyokong" semangat suaminya untuk terus berjihad di jalanNya. Mampu menjaga dirinya dan mewakili suaminya memimpin rumah tangganya yang sewaktu-waktu ditinggal oleh suami ke medan jihad. Sebagaimana yang juga disampaikan AS secara formal dalam kata pengantar yang dipersembahkannya untuk buku yang ditulis oleh almarhum suaminya berikut ini:

\begin{abstract}
" Tarbiyah yang kami pahami dan yakini bahwa perjalanan hidup seseorang muslim terlebih seorang mujahid pasti mempunyai konsekuensi tersendiri dan itu adalah sunnatullah. Maka ketika terjadi resiko apapun pada keluarga kami dan itu disebabkan oleh sebuah kebenaran yang kami amalkan, tidak sepantasnya kami sebagai istri untuk berkeluh kesah, menghujat orang lain apalagi menghujat Allah, karena semua itu akan mewujudkan kami seorang istri yang tidak sabar, tidak ridlo terhadap taqdir Allah yang pada akhirnya menghapuskan semua jaza' (pahala) yang selalu kami idam-idamkan."
\end{abstract}

AS memaknai semua peristiwa yang terjadi dengan keluarganya dalam kurun waktu sepuluh tahun terakhir ini sebagai serangkaian cobaan dan sekaligus rahmat dari Allah untuk dirinya, almarhum suaminya, dan seluruh keluarganya.

\title{
Simpulan
}

Berdasarkan pembahasan data dan analisis yang telah dilakukan, akhirnya dapat disimpulkan bahwa keluarga teroris dari awal sudah menunjukkan proses redefinisi atas identitasnya sebagai keluarga teroris dengan mengatakan bahwa "kami" memang "berbeda" dengan keluarga lain yang ada di masyarakat pada umumnya. Perbedaan yang dimaksud terkait dengan adanya beberapa hal yang dijadikan sebagai "prinsip" hidup dan berlandaskan pada aqidah Islam yang diyakini dan harus tetap dipegang keluarga teroris. Proses pemahaman atas identitas diri sebagai keluarga teroris ini menjadikan mereka harus melakukan sebuah "kompromi" antara diri mereka dan "prinsip" yang dipegang dengan diri mereka dalam kehidupan sosial kemasyarakatannya, sehingga "perbedaan" tersebut tidak membuat mereka menjadi tertutup dan tidak berinteraksi dengan masyarakat luas.

Identitas sebagai keluarga teroris ini dimaknai oleh keluarga teroris sendiri sebagai sebuah "kebanggaan" bagi seluruh keluarga besar. Banyak hal dan peristiwa yang kemudian semakin menguatkan keyakinan keluarga teroris atas kebenaran dari tindakan para "syuhada" sendiri. Keluarga merasa mendapatkan "karomah" sekaligus memiliki derajat dan harkat martabat yang "lebih baik" dan didudukan pada dalam status sosial yang lebih "tinggi" ditengah-tengah masyarakat luas. Makna tersebut lebih diarahkan pada munculnya sebuah perasaan "kerahmatan" dan "kemuliaan" yang diterima keluarga teroris sendiri dan harus ditransformasikan menjadi sebuah "amanah" bersama bagi keluarga untuk terus "melanjutkan" amalan para "syuhada" dengan tanpa harus menggunakan "cara- 
cara" yang sama sebagaimana yang dilakukan oleh para "syuhada" sebelumnya.

\section{Daftar Pustaka}

Akaha, AZ (2002) Terorisme dan konspirasi anti Islam. Jakarta: Pustaka Al Kautsar.

Hilmy M (2009) Membaca agama: Islam sebagai realitas terkonstruksi. Yogyakarta: Kanisius.

Ritzer,. George,. dan Goodman DJ (2004) Teori sosiologi modern. Jakarta: Prenada Media Group.

Rosyadi MA (2004) Tafsir Sosial Jihad: studi tentang konstruksi sosial jihad gerakan Islam pada

masa Nabi Muhammad dan masa kontemporer di Indonesia (Muhammadiyah, NU, PKS, dan MMI). Surabaya: FISIP Universitas Airlangga.

Salam MF (2005) Motivasi tindakan terorisme. Bandung: CV. Mandar Maju.

Suyanto,. Bagong,. dan Sutinah (ed) (2005) Metode pnelitian sosial. Jakarta: Kencana Prenada Media. 